\title{
FORMATIVE PERIOD AND MIDDLE HORIZON OCCUPATIONS AT THE HUARACANE SETTLEMENT OF YAHUAY ALTA IN THE MIDDLE MOQUEGUA VALLEY, PERU
}

\author{
LAS OCUPACIONES EN EL ASENTAMIENTO DE HUARACANE (YAHUAY ALTA) \\ DURANTE EL PERIODO FORMATIVO Y HORIZONTE MEDIO EN EL VALLE \\ MEDIO DE MOQUEGUA, PERÚ
}

\author{
Kirk E. Costion ${ }^{1}$
}

\begin{abstract}
The issue of late Huaracane contemporaneity with Wari and Tiwanaku colonies in Moquegua valley has been particularly vexing for researchers. No currently published radiocarbon dates can confirm that Huaracane settlements in the valley were occupied after AD 340. Yet until recently, no dates were taken from domestic contexts. During the 2006 field season, eight new radiocarbon dates were taken from the Huaracane settlement of Yahuay Alta. The contexts for these dates and how they fit within the established regional chronology will be discussed. This research represents an important step towards understanding the relationship between indigenous Huaracane agriculturalists and Middle Horizon colonists.
\end{abstract}

Key words: Moquegua valley, Huaracane, Formative period, Middle Horizon, radiocarbon dates.

\begin{abstract}
La problemática del asentamiento de Huaracane tardío, contemporáneo con colonias de Wari y Tiwanaku en el valle medio de Moquegua ha sido particularmente molesto para los investigadores. Ninguna de las fechas de radiocarbono publicadas actualmente han confirmado que los asentamientos Huaracane en el valle fueron ocupadas después de los 340 d.C. Aun hasta hace poco no se conocía ninguna datación proveniente de contextos domésticos. Durante la temporada de campo del año 2006, fueron tomadas ocho muestras desde contextos domésticos del sitio Huaracane de Yahuay Alta, con el propósito de afinar la cronología regional establecida. Por otro lado, esta investigación representa un paso importante hacia el entendimiento de la relación entre los agricultores locales de Huaracane y las colonias Tiwanaku y Wari.
\end{abstract}

Palabras claves: valle de Moquegua, Huaracane, período Formativo, Horizonte Medio, fechas de radiocarbono.

Prior to the establishment of the well documented Wari and Tiwanaku colonies in the Moquegua valley during the Middle Horizon (e.g., Goldstein 1993a, b, 2000a, 2005; Moseley et al. 1991; Williams 2001, 2002; Williams and Nash 2002), indigenous small scale agriculturalists thrived in this region creating a virtually continuous occupation of small residential villages associated with the distinctively local Huaracane ceramic style in the middle valley (Feldman 1989; Goldstein 2000b, 2005). These Huaracane residential sites were generally small in size, less than 0.5 hectares, and located close to the floodplain of the Rio Moquegua, suggesting a reliance upon simple valley-edge canals to irrigate agricultural fields (Goldstein 2000:343). The Huaracane agricultural system was relatively simplistic in comparison to other contemporary Formative Period agricultural systems developed elsewhere in the south central Andes (see Wernke 2011)" To date, no clearly identifiable Huaracane economic or political centers have been identified. In general Huaracane residential settlements appear to have been fundamentally autonomous. Nevertheless there is evidence, derived primarily from mortuary contexts, suggesting that towards the end of the previously established Huaracane sequence (385 Cal BC-Cal AD 340), there was an emergence of an elite and/or prestigious social class that likely represented "petty local chiefs" (Goldstein 2005:311).

Although it is clear that the middle Moquegua valley was heavily populated by indigenous Huaracane farmers during the regional Formative period, it is not clear how or even if Huaracane communities interacted with intrusive Wari and Tiwanaku colonists when they arrived in the region. This is because until recently the latest published confirmed date for Huaracane presence in the middle Moquegua valley was AD 340 (Goldstein 2000b:Table 3, 2005:Table 5.2), and the earliest

$\overline{1}$ Humanities and Social Science Department Oglala Lakota College P.O. Box 490 Kyle, SD 57752 U.S.A. kirkcostion@ gmail.com 
documented date for both Wari and Tiwanaku in the region was approximately AD 550 (Goldstein 2005:Table 5.2; Moseley et al. 2005:Table 1). As Goldstein (2005:132) has observed, "No Huaracane site in the middle Moquegua valley has yet produced dates that overlap with the Tiwanaku occupation, and the issue of late Huaracane contemporaneity with Tiwanaku has not been resolved". Owen (2005:51) believes that the presence of a few Wari sherds found at Huaracane sites indicates that the indigenous inhabitants of the region shared the valley with the Tiwanaku and the Wari "...for at least part of the Middle Horizon". However, this observation was not confirmed by any published radiocarbon dates. This situation is complicated by the intriguing fact that although the majority of both Huaracane and Tiwanaku settlements were located in the middle valley region, not one Huaracane style artifact has been found in Tiwanaku contexts, and vice versa (Goldstein 2005).

In order to obtain a better understanding of Huaracane social organization and to better define the chronology of the Huaracane sequence, I chose to investigate the Huaracane site of Yahuay Alta, located in the middle Moquegua valley (Figure 1). This article reports on the results of the systematic excavation of both domestic and public ceremonial contexts at Yahuay Alta. These results will provide the first published detailed descriptions of Huaracane domestic contexts. In addition, radiocarbon dates taken from Yahuay Alta will be presented; these dates provide some of the first published unequivocal evidence that at least some Huaracane communities persisted in the middle Moquegua valley well after Wari and Tiwanaku colonists entered the region. The aforementioned dates along with other evidence from the excavations at Yahuay Alta also demonstrate how Huaracane households and social organization changed over time and the extent of interaction that took place between the Middle Horizon community at Yahuay Alta and their colonial neighbors.

\section{The Huaracane Settlement of Yahuay Alta}

\section{Site location}

Yahuay Alta is situated high upon the southwestern flanks of Cerro Estuquiña, one of the mountains that demarcates the boundary between the upper and middle valley sections of the Moquegua valley ${ }^{1}$ (see Figure 1). This mountain is located just across the
Rio Huaracane from the Pampa Huaracane. Yahuay Alta is the northernmost of the 169 known Huaracane habitation sites, and therefore is on the northern margin of what can be considered Huaracane territory (Goldstein 2000b, 2005). Given this geographic location and its relatively high elevation in comparison to typical Huaracane settlements, Yahuay Alta is situated just outside the hyper-arid zone of the middle Moquegua valley in which archaeological sites exhibit truly exceptional organic preservation. Thus, none of the more fragile organic materials, such as woven textiles or basketry, found at other Huaracane sites at lower elevations in the middle valley (see Goldstein 2000b) were recovered during excavations at Yahuay Alta.

Generally, Huaracane settlements throughout the middle Moquegua valley were situated upon hilltops that were on average only $48 \mathrm{~m}$ in elevation above the Rio Moquegua (Goldstein 2000b:343, 2005:123). However, with an average elevation of approximately 1600 masl, the settlement at Yahuay Alta is some $140 \mathrm{~m}$ above the Rio Huaracane, nearly three times the average elevation above the riverbed for Huaracane settlements. As a result, there are no natural sources of water at the site of Yahuay Alta, thus its residents would have had to carry all water needed for daily activities and consumption from the Rio Huaracane. In addition, the settlement at Yahuay Alta was not easily accessible (see Figure 2). There are two identifiable access routes and a third possible route to the settlement of Yahuay Alta, none of which involve simple walks from the river or the adjacent agricultural fields. Although no defensive works have been found associated with Yahuay Alta, the site was not easily reached and is situated in an easily defendable location.

\section{The settlement at Yahuay Alta}

The entire settlement at Yahuay Alta covers approximately 4 ha and is spread over a series of six narrow ridges that were terraced for habitation, and are separated from one another by deep quebradas. From the top of these ridges one commands an excellent view of the middle Moquegua valley floodplain, where the majority of Huaracane agricultural fields would have been located (Goldstein 2000b). The terraces on the four easternmost ridges were relatively small, generally not very well preserved, and the surface artifact density was relatively low. In contrast, the preservation of the terraces on the 


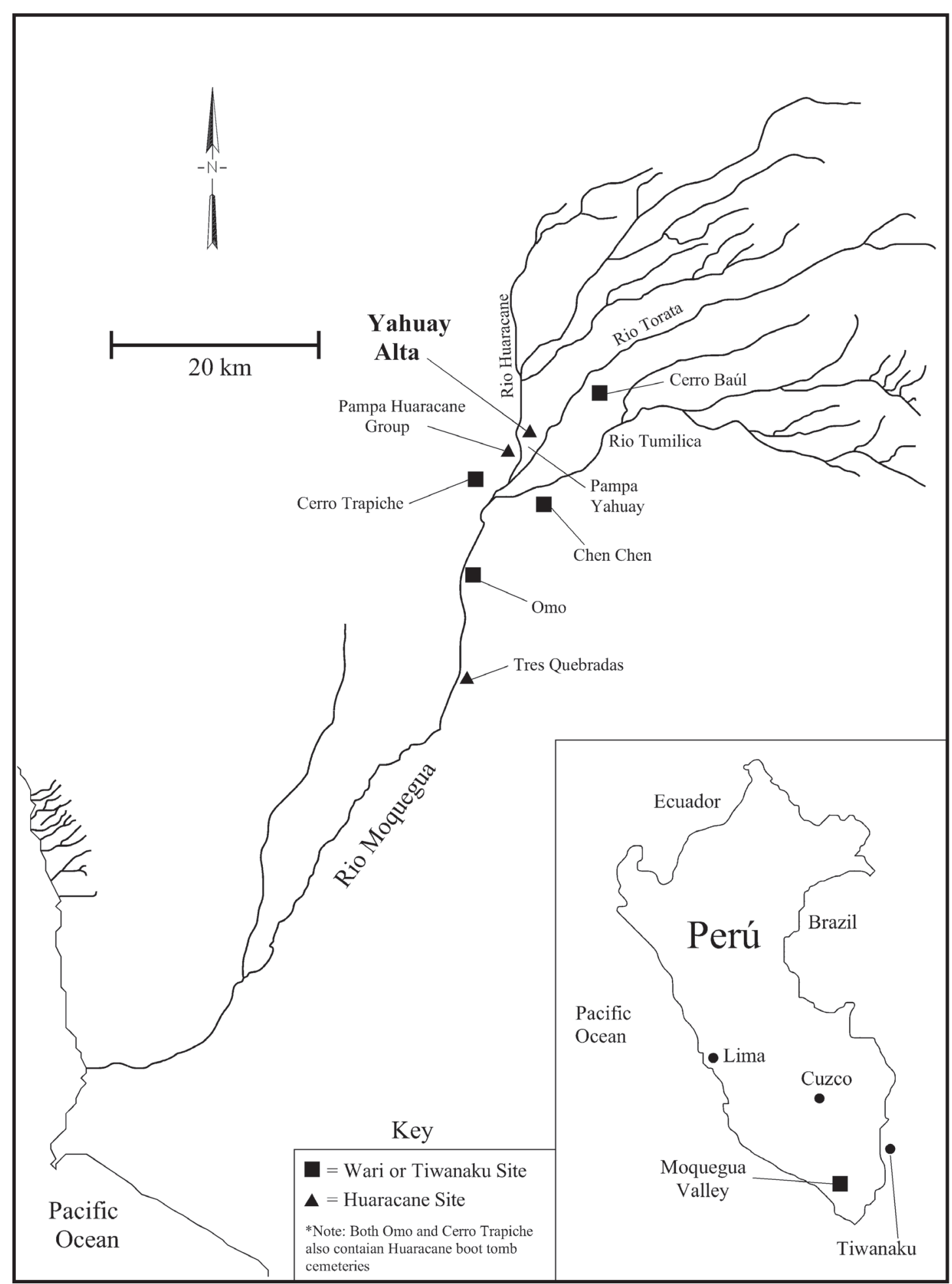

Figure 1. Map of the Moquegua valley showing the location of Yahuay Alta in relation to other important sites and landmarks in the region (adapted from Williams and Nash 2002:Figure 8.1).

Mapa del valle Moquegua mostrando la ubicación de Yahuay Alta con relación a otros sitios importantes y señales en la región (adaptado de Williams y Nash 2002:Figura 8.1). 
two westernmost ridges was substantially better and the surface artifact density on these terraces was substantially higher. In addition, all evidence for public architecture was located on these two western most ridges. Consequently, this research project focused only upon the two western most ridges at this site where the preservation was better, the surface artifact density was higher, and there was both residential and public architecture. All subsequent discussions of Yahuay Alta will be referring to only the two westernmost ridges at the site.

The residential occupation on the two westernmost ridges at Yahuay Alta consists of five spatial sectors (totaling approximately $2.3 \mathrm{ha}$ ) of house remains situated upon terraces, separated from one another by steep sided quebradas and other natural topographic features (Figures 2 and 3). In total, 120 residential terraces were identified at the site during the surface collection phase of research at Yahuay Alta. These residential terraces are not uniform in shape or size; some are relatively small and circular and others are relatively large and rectangular. Terraces ranged in size from $4 \mathrm{~m}^{2}$ up to $134.6 \mathrm{~m}^{2}$, with a median size of $18.75 \mathrm{~m}^{2}$. Over $50 \%$ of these terraces were between $10 \mathrm{~m}^{2}$ and $25 \mathrm{~m}^{2}$. In general, the domestic architecture is readily visible upon the surface. Stone foundations and walls are preserved up to roughly a meter in height in many structures and terraces. Some houses were constructed with stone foundations and walls, while others were constructed of organic materials that are not preserved on the surface.

The two westernmost ridges at Yahuay Alta also contain extensive public architecture including two elevated platforms and a large artificial platform mound. The southern elevated platform (P1 in Figure 3) is approximately $265 \mathrm{~m}^{2}$ and stands roughly $1 \mathrm{~m}$ above a relatively open plaza area to its northern and western sides. This open area is at the base of a natural hill, which is ringed by domestic terraces and topped by the northern elevated platform (P2 in Figure 3). This platform is approximately $281 \mathrm{~m}^{2}$ and stands roughly $2 \mathrm{~m}$ above the large crescent shaped terrace directly to its south. Located above the northern elevated platform are the largest and most elaborate residential structures at the site.

The platform mound is approximately $700 \mathrm{~m}^{2}$ at its base and approximately $8 \mathrm{~m}$ in height. It is located directly in front of a large, $933 \mathrm{~m}^{2}$, artificially leveled, open plaza that contains the remains of a small wall in its eastern sector. Although heavily deteriorated, this mound appears as if it was originally faced with roughly cut stone blocks that are

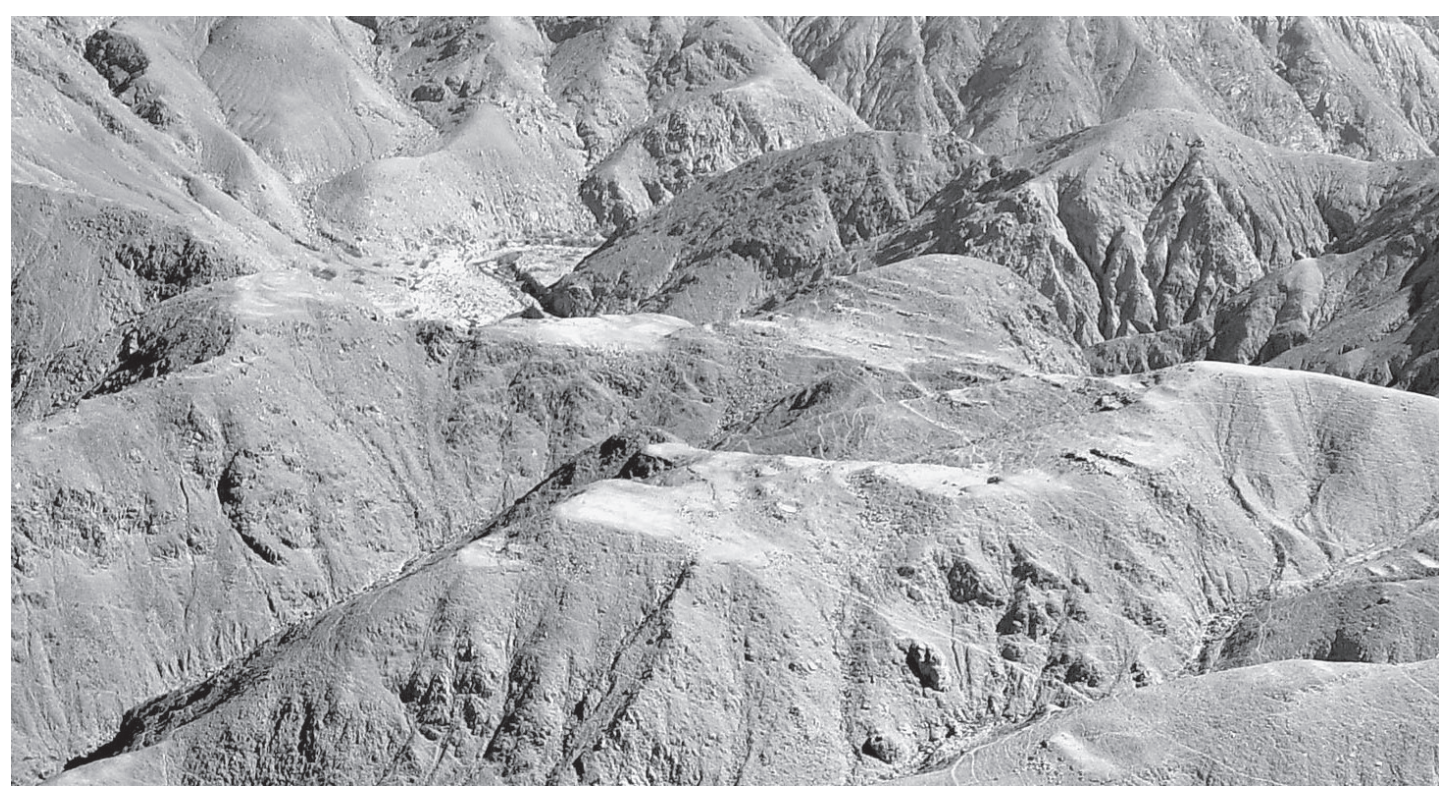

Figure 2. Photograph of two western most ridges of Yahuay Alta emphasizing the steep relief of Cerro Estiquiña and the resulting relative inaccessibility of this settlement (photograph taken during a helicopter flyover by Patrick Ryan Williams in 2004). Fotografía de dos cordilleras occidentales de Yahuay Alta destacando el relieve escarpado del cerro Estiquiña y la inaccesibilidad relativa resultante de este asentamiento (fotografía tomada por Patrick Ryan Williams durante un sobrevuelo de helicóptero en 2004). 


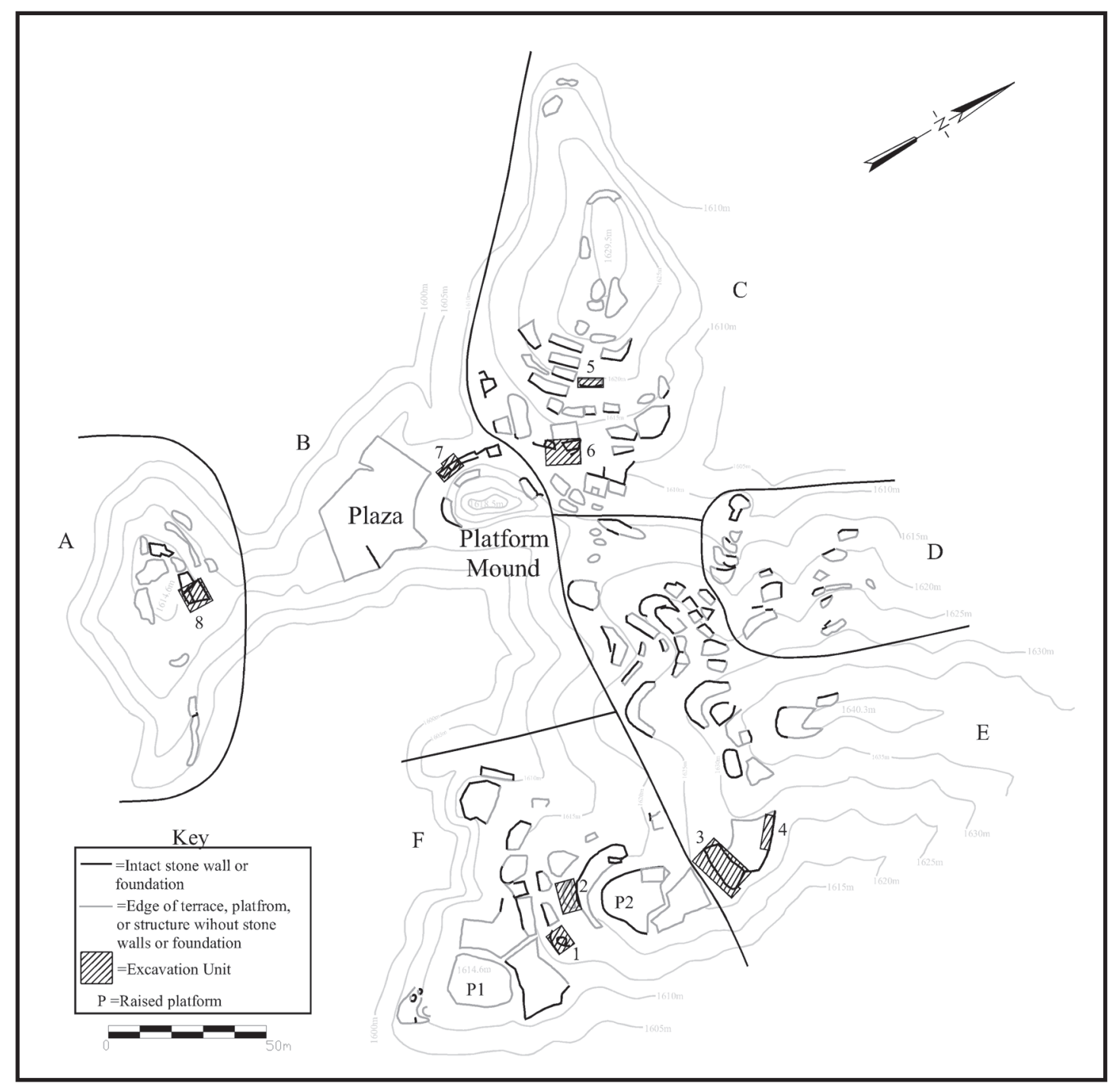

Figure 3. Map of Yahuay Alta showing the sector divisions and the location of excavation units ${ }^{2}$.

Mapa de Yahuay Alta mostrando las divisiones de sectores y ubicación de las unidades de excavación ${ }^{2}$.

geologically distinct from the bedrock it is situated upon. The mound is flanked on its west side by three small contiguous structures and contains a narrow terrace halfway up its southern side, which faces the open plaza. There is no evidence of structures on the summit of the platform mound or either of the raised platforms.

\section{Radiocarbon dates from Yahuay Alta}

Excavations at Yahuay Alta consisted of broad horizontal units designed to uncover entire domestic terraces. In most contexts this strategy allowed for the excavation of both internal and external space.
During the 2006 field season, eight terraces were excavated in their entirety; seven of these terraces were located in domestic sectors of the site and one was located in the public sector of the site directly adjacent to the platform mound (see Figure 3). All excavation units were subdivided into $1 \mathrm{x} 1 \mathrm{~m}$ grids to maintain spatial control of recovered artifacts and excavations were conducted by natural layers. In total, approximately $455 \mathrm{~m}^{2}$ was uncovered during the excavation phase of fieldwork.

An important goal of the research conducted at Yahuay Alta was to determine how the occupation of this site fit into the known Huaracane sequence. To this end, during the excavations 25 
samples for radiocarbon dating were taken from the eight excavation units. Eight of these samples, one from each excavation unit, were submitted to the University of California Irvine's Keck laboratory facility for AMS radiocarbon analysis. Following this analysis, each date was calibrated using the IntCal04 calibration curve (Reimer et al. 2004). The results of this analysis resulted in two distinct clusters of dates, which demonstrate that Yahuay Alta was inhabited both during the later part of the previously established Huaracane sequence and the early part of the Middle Horizon (Table 1).

The earlier cluster consists of three dates from Units 1, 2, \& 4, that range between Cal AD 79 and $\mathrm{Cal} \mathrm{AD} 323$ at the 2 sigma range. The median dates place this occupation of Yahuay Alta primarily during the $2^{\text {nd }}$ century and possibly into the $3^{\text {rd }}$ century AD. Thus this occupation falls towards the end of the established Huaracane sequence during the time period when boot tombs were being constructed (Goldstein 2000b, 2005). I have chosen to term this time period at Yahuay Alta as the Late Huaracane phase, because it corresponds with the later part of the previously established Huaracane sequence. All three contexts that date to this time period are located within the eastern half of Yahuay Alta.

The later cluster of radiocarbon dates consists of five dates from Units 3, 5, 6, 7, and 8, that range between Cal AD 676 and Cal AD 885 at the 2 sigma range. The median dates indicate that this occupation of Yahuay Alta occurred primarily during the $8^{\text {th }}$ century AD. This cluster of dates falls well outside the established Huaracane sequence and places a portion of the occupation of Yahuay Alta squarely in the early Middle Horizon. As mentioned briefly above, these are the first dates from a confirmed Huaracane settlement context that demonstrate contemporaneity with the Wari and Tiwanaku colonies in the valley. There is overlap with occupations at the Wari sites of Cerro Baúl, Cerro Mejia, and Cerro Trapiche and with occupations at the Tiwanaku sites of Omo and Chen Chen (Goldstein 2005:Table 5.2;

Table 1. Radiocarbon dates from Yahuay Alta.

Fechas radiocarbónicas de Yahuay Alta.

\begin{tabular}{|c|c|c|c|c|c|c|c|c|}
\hline Sample & Context & Material & $\begin{array}{c}\text { Radiocarbon } \\
\text { Age }\end{array}$ & $\begin{array}{c}\text { Calibrated } \\
\text { Intercept Date }\end{array}$ & $\begin{array}{c}\text { Calibrated } \\
\text { 1 Sigma Ranges }\end{array}$ & Prob. & $\begin{array}{c}\text { Calibrated } \\
2 \text { Sigma Ranges }\end{array}$ & Prob. \\
\hline UCI-43615 & Unit 1 & Burnt wood & $1,825 \pm 20 \mathrm{BP}$ & Cal AD 184 & $\begin{array}{l}\text { Cal AD 138-159 } \\
\text { Cal AD 166-197 } \\
\text { Cal AD 207-227 }\end{array}$ & $\begin{array}{l}(0.287) \\
(0.434) \\
(0.280)\end{array}$ & Cal AD 131-238 & (1.000) \\
\hline UCI-43616 & Unit 2 & Burnt wood & $1,790 \pm 20 \mathrm{BP}$ & $\mathrm{Cal}$ AD 234 & $\begin{array}{l}\text { Cal AD 177-189 } \\
\text { Cal AD 212-257 } \\
\text { Cal AD 300-318 }\end{array}$ & $\begin{array}{l}(0.096) \\
(0.734) \\
(0.171)\end{array}$ & $\begin{array}{l}\text { Cal AD 137-259 } \\
\text { Cal AD 284-289 } \\
\text { Cal AD 291-323 }\end{array}$ & $\begin{array}{l}(0.827) \\
(0.009) \\
(0.163)\end{array}$ \\
\hline UCI-43617 & Unit 3 & Burnt wood & $1,215 \pm 20 \mathrm{BP}$ & Cal AD 813 & $\begin{array}{l}\text { Cal AD 775-827 } \\
\text { Cal AD 839-865 }\end{array}$ & $\begin{array}{l}(0.683) \\
(0.317)\end{array}$ & $\begin{array}{l}\text { Cal AD 719-742 } \\
\text { Cal AD 769-885 }\end{array}$ & $\begin{array}{l}(0.073) \\
(0.927)\end{array}$ \\
\hline UCI-43618 & Unit 4 & Burnt wood & $1,870 \pm 20 \mathrm{BP}$ & Cal AD 130 & $\begin{array}{c}\text { Cal AD 83-139 } \\
\text { Cal AD 157-167 } \\
\text { Cal AD 196-208 }\end{array}$ & $\begin{array}{l}(0.791) \\
(0.086) \\
(0.122)\end{array}$ & Cal AD 79-216 & (1.000) \\
\hline UCI-43707 & Unit 5 & Burnt wood & $1,235 \pm 20 \mathrm{BP}$ & Cal AD 772 & $\begin{array}{l}\text { Cal AD 710-746 } \\
\text { Cal AD 766-782 } \\
\text { Cal AD 789-812 } \\
\text { Cal AD 845-856 }\end{array}$ & $\begin{array}{l}(0.463) \\
(0.225) \\
(0.238) \\
(0.075)\end{array}$ & $\begin{array}{l}\text { Cal AD 690-750 } \\
\text { Cal AD 762-871 }\end{array}$ & $\begin{array}{l}(0.415) \\
(0.585)\end{array}$ \\
\hline UCI-43619 & Unit 6 & Burnt wood & $1,230 \pm 20 \mathrm{BP}$ & Cal AD 788 & $\begin{array}{l}\text { Cal AD 717-743 } \\
\text { Cal AD 768-783 } \\
\text { Cal AD 788-819 } \\
\text { Cal AD 842-859 }\end{array}$ & $\begin{array}{l}(0.309) \\
(0.203) \\
(0.344) \\
(0.144)\end{array}$ & $\begin{array}{l}\text { Cal AD 693-748 } \\
\text { Cal AD 765-876 }\end{array}$ & $\begin{array}{l}(0.304) \\
(0.696)\end{array}$ \\
\hline UCI-43708 & Unit 7 & S. molle seed & $1,230 \pm 20 \mathrm{BP}$ & Cal AD 788 & $\begin{array}{l}\mathrm{Cal} \text { AD 717-743 } \\
\mathrm{Cal} \text { AD 768-783 } \\
\text { Cal AD 788-819 } \\
\text { Cal AD 842-859 }\end{array}$ & $\begin{array}{l}(0.309) \\
(0.203) \\
(0.344) \\
(0.144)\end{array}$ & $\begin{array}{l}\text { Cal AD 693-748 } \\
\text { Cal AD 765-876 }\end{array}$ & $\begin{array}{l}(0.304) \\
(0.696)\end{array}$ \\
\hline UCI-43709 & Unit 8 & Burnt wood & $1,260 \pm 20 \mathrm{BP}$ & Cal AD 730 & $\begin{array}{l}\text { Cal AD 694-748 } \\
\text { Cal AD 765-773 }\end{array}$ & $\begin{array}{l}(0.867) \\
(0.133)\end{array}$ & $\begin{array}{l}\text { Cal AD 676-779 } \\
\text { Cal AD 794-802 }\end{array}$ & $\begin{array}{l}(0.983) \\
(0.017)\end{array}$ \\
\hline
\end{tabular}


Green and Goldstein 2010: Table 2.1; Moseley et al. 2005:Table 1; Williams 2001:Table 1). Although these are the first confirmed Middle Horizon Huaracane dates from a Huaracane settlement, it is of note that recent research in the middle Moquegua valley, especially at the Wari settlement of Cerro Trapiche (see Figure 1), has also found evidence demonstrating Huaracane presence in the region during the Middle Horizon (Costion and Green 2009; Green and Goldstein 2010). I have chosen to term this time period at Yahuay Alta as the Terminal Huaracane phase, because it likely represents the final time period when the distinctive Huaracane material culture was used in the Moquegua valley, although in the established chronology of the greater region of the south central Andes this time period corresponds to the early Middle Horizon. All of the contexts that date to this time period, with the exception of Unit 3, are located in the western half of Yahuay Alta relatively close to the platform mound.

The radiocarbon dates discussed above demonstrate that Yahuay Alta was a multi-component site inhabited during two distinct time periods. Interestingly this site exhibits horizontal rather than vertical stratification. In all but one excavated context, Unit 6, at Yahuay Alta there is no evidence for superimposed occupations. Unfortunately, in Unit 6 no appropriate samples for radiocarbon dating were obtained from the lower occupation layer. Thus the apparently earlier occupation in this context has not been securely dated. Nevertheless, it appears that the eastern half of Yahuay Alta was primarily inhabited during the Late Huaracane phase and the western half of the site was primarily inhabited during the Terminal Huaracane phase. This pattern is further exhibited by the differential distribution of utilitarian ceramic wares across the surface of the site, with Huaracane Arena being more prevalent in the eastern half and Huaracane Fibre Vegetal being more prevalent in the western half. As the presence of Unit 3, a Terminal Huaracane context in the eastern half of Yahuay Alta, suggests the horizontal stratification of this site was not absolute. However, based on current evidence each half of the site does appear to correspond primarily to a single phase of occupation.

\section{Late Huaracane Contexts at Yahuay Alta}

All of the structures that dated to the Late Huaracane were located in the eastern half of
Yahuay Alta and are relatively distant from the site's platform mound (see Figure 3). The structures dating to this time period at Yahuay Alta were universally small in size, roughly circular in shape, and constructed primarily from organic materials. Thus these contexts were similar to descriptions of typical Huaracane sites located throughout the middle Moquegua valley. For example, at the middle valley site of Tres Quebradas (see Figure 1) it has been interpreted that most of the structures there were constructed of organic material and modern damage caused by a bulldozer to this site revealed the plan of one small domestic structure that was circular in shape with a concave floor dug into a domestic terrace (Bandy 1995:3). The ceramics recovered from these contexts at Yahuay Alta were all typical Huaracane wares including Huaracane Arena, Huaracane Fibre Vegetal, and Huaracane Fino (see Feldman 1989; Goldstein 1989, 2005). The only exotic material found in Late Huaracane phase contexts was marine shell and this was found only in very small quantities.

The circular living floors of Late Huaracane structures had approximate maximum diameters ranging in size from $1.8 \mathrm{~m}$ to $3 \mathrm{~m}$. All of these structures were relatively simple and seemed to be constructed nearly entirely of organic materials such as reed quincha and/or wooden posts. None of the structures exposed in Late Huaracane contexts had stone walls of any kind, but some of the terraces these structures were constructed upon had stone in their retaining walls. There was no evidence for any kind of permanent hearths or other common domestic features within these structures, and their living floors were all kept relatively clean. This evidence seems to suggest that all of the dwellings from this time period were small simple domestic structures designed to shelter sleeping residents from the wind. These structures would have at most only been able to adequately accommodate small nuclear family households and probably only represent a portion of larger household units (e.g. Flannery 1983:45) consisting of more than one of these small structures. Given the small size of the Late Huaracane structures, there is little doubt that the majority of domestic activities during this time period took place in exterior space.

The structure exposed during the excavations in Unit 1 had a very circular level living surface approximately $2.1 \mathrm{~m}$ in diameter (Figure 4). The back or north wall of this structure was carved or 


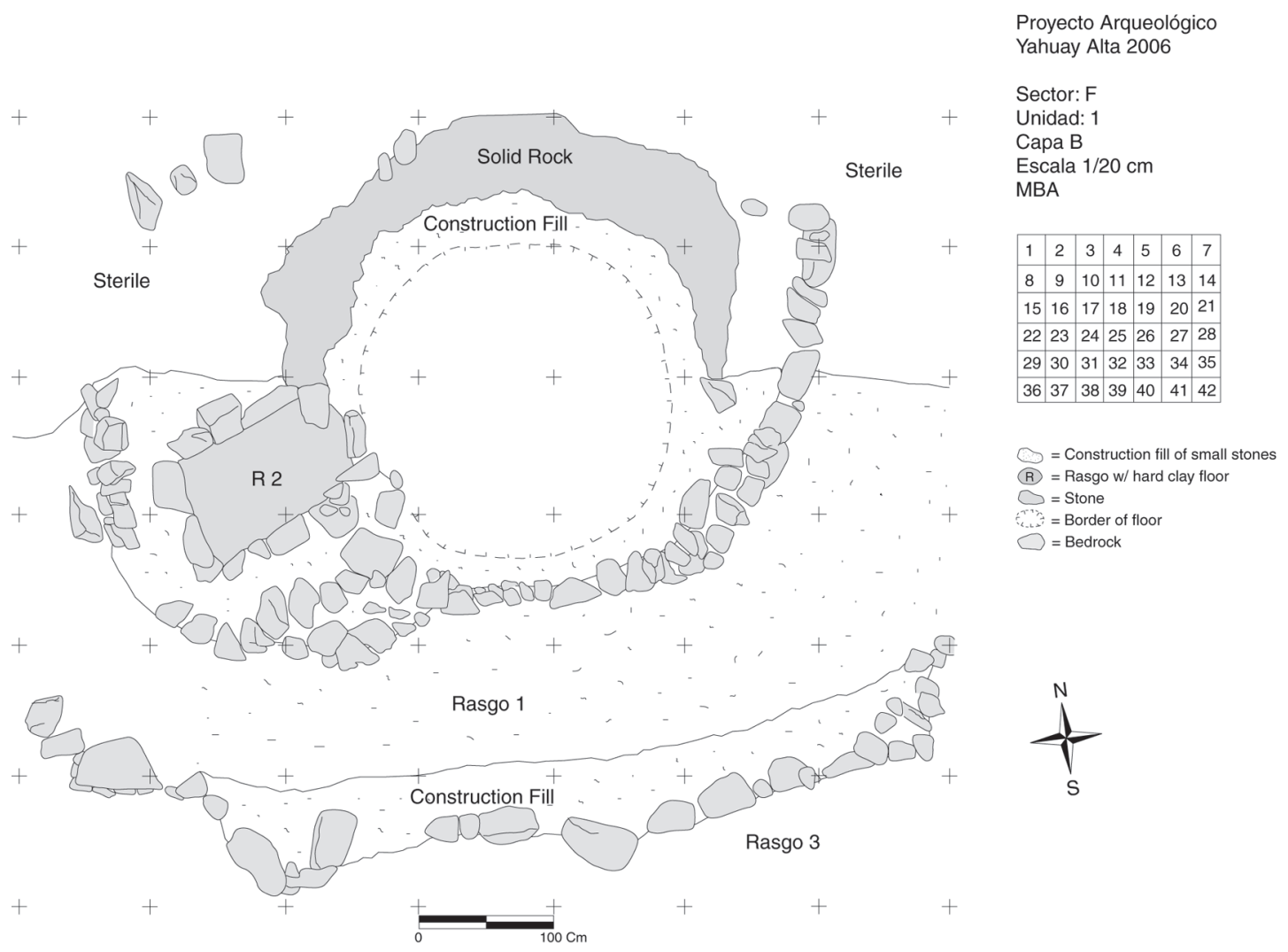

Figure 4. Plan view drawing of Unit 1 excavated to the surface of occupation (drawn by Monika Barrionuevo Alba). Vista del plano de la Unidad 1 excavado en la superficie de ocupación (dibujado por Monika Barrionuevo Alba).

chipped out of the bedrock. The rubble from this activity was used as construction fill for the small terrace and its slightly curving retaining wall, which is between 1 and $1.5 \mathrm{~m}$ south of the structure itself. On the surface, the front wall of this structure looked as if it had a curving stonewall foundation. However, excavations revealed that this curving line of stones bordering the structure was not a substantial structural foundation; it was simply a line of stones. This line of stones appears as if it was used to support a lightweight reed quincha wall. Although the living surface of this structure was no more than $2.1 \mathrm{~m}$ in diameter, the curving line of rocks that possibly supported a quincha wall had an approximate diameter of $5.2 \mathrm{~m}$. This wall enclosed not only the living surface but also a relatively small rectangular basin. Located just west of the living floor, this basin had three well-made stone walls and a well-prepared hard clay floor.

The excavation of Unit 4 exposed two poorly preserved small circular structures (Figure 5).
They are located along the northeastern edge of a large artificially leveled plaza-like open area that appears to date to the Terminal Huaracane phase. The construction activities associated with the leveling of this plaza damaged the older domestic structures excavated in Unit 4. Both of the structures exposed in Unit 4 seem to be similar to the structure in Unit 1. They consist of circular depressions that were excavated into the bedrock, and the rubble from this was used as a foundation for the structures' walls. The northern structure had a living floor with an approximate maximum diameter of $3.1 \mathrm{~m}$ and the southern structure had a living floor with an approximate maximum diameter of $1.8 \mathrm{~m}$. It is of note that this smaller southern structure was quite badly damaged; slightly less than half of the living surface appears to be intact. As a result, the actual maximum diameter of this living surface was probably larger than $1.8 \mathrm{~m}$. Unfortunately, because of the damage to these structures by the later construction activities 


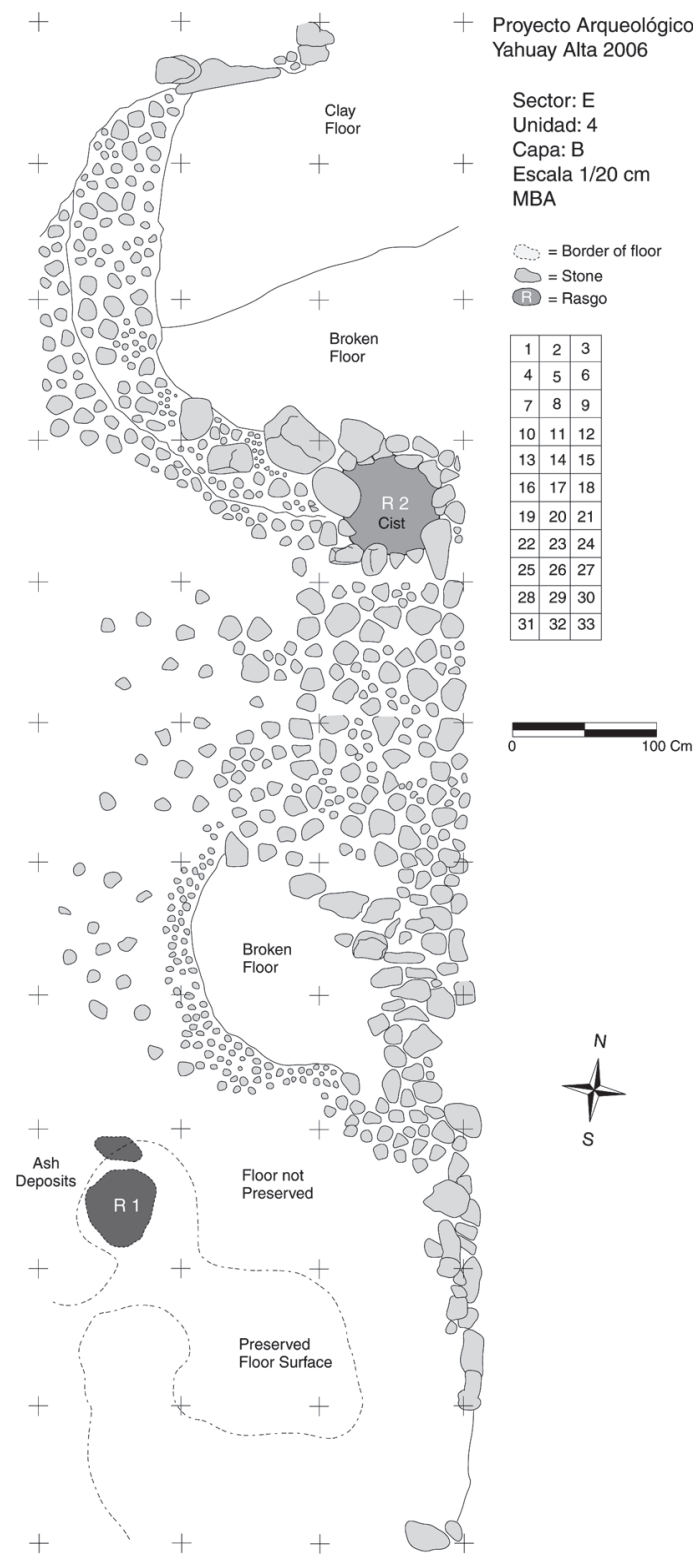

Figure 5. Plan view drawing of Unit 4 excavated to the surface of occupation (drawn by Monika Barrionuevo Alba).

Vista del plano de la Unidad 4 excavado en la superficie de ocupación (dibujado por Monika Barrionuevo Alba).

mentioned above, it is difficult to tell exactly how the walls of these structures were constructed and whether or not the walls enclosed a space larger than the actual living floors as what appears to have been the case with the structure in Unit 1. No postholes were discovered during the excavation of these structures suggesting that they may have had simple reed quincha walls supported is a similar way to the walls of the structure in Unit 1.
One of the unique features of the structures in Unit 4 was that the northern half of the northern structure had a partially preserved prepared clay floor. This was the only prepared living surface found in Late Huaracane contexts. A possible storage feature was found in Unit 4 just south of the northern structure. This feature was a $67 \mathrm{~cm}$ deep cist or pit with a ring of stones marking its opening. This cist was looted in antiquity prior to the eruption of the Huaynaputina Volcano in 1600 AD (see de Silva et al. 2000), and it is therefore not clear whether or not it was a storage feature or a tomb disturbed in antiquity.

The excavation of Unit 2 discovered evidence for one structure and possible evidence for a very badly preserved second structure (Figure 6). The evidence suggests that this structure was very different than the structures exposed in Units 1 and 4 described above. Unit 2 consisted of a large, flat, and roughly rectangular terrace with a very low and badly preserved front retaining wall. In the southwestern part of the terrace, there is a curvilinear line of five postholes averaging approximately $15 \mathrm{~cm}$ in diameter. This evidence suggests there was a small, approximately $3 \mathrm{~m}$ in diameter, structure with walls supported by sturdy wooden posts in this section of the terrace. There is no posthole evidence that this structure was completely circular, suggesting the posts may have supported a simple windbreak or lean-to-like structure. To the east of this line of postholes, there are three more postholes that are more spaced out. These could possibly have been postholes for another simple windbreak for which some of the postholes were not preserved. In sum, the structures discovered in Unit 2 differed from those found in Unit 1 and 3 because they appear to have been half circular structures or windbreaks instead of circular structures partially dug into the surface of the site.

\section{Terminal Huaracane Contexts at Yahuay Alta}

All of the Terminal Huaracane structures, with the exception of Unit 3, were located in the western half of Yahuay Alta relatively close to the site's platform mound. Contexts dating to this time period are rather different from typical Huaracane sites located throughout the middle Moquegua valley. All of the Terminal Huaracane phase structures were approximately rectilinear in shape, although there was a large amount of variation in their size. 


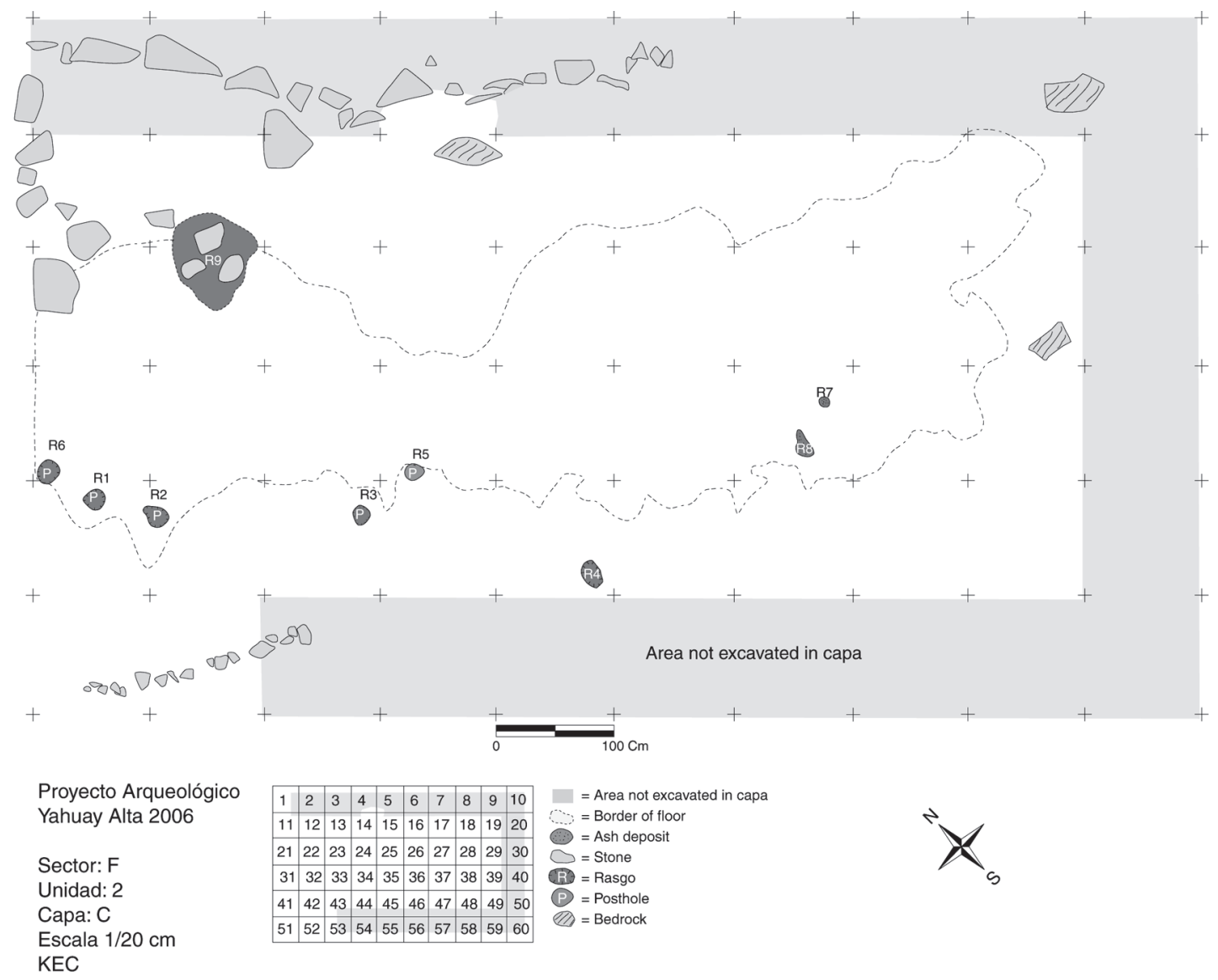

Figure 6. Plan view drawing of Unit 2 excavated to the surface of occupation.

Vista del plano de la Unidad 2 excavado en la superficie de ocupación.

In addition, all of these structures had stone foundations and some originally had walls constructed at least partially from stone. The typical Huaracane ceramic wares mentioned above were predominate in these contexts, however some atypical plainware ceramics were found as well. The most common of these atypical wares contained a large amount of biotite mica temper and was used to make large utilitarian vessels; this ware is similar to plainware ceramics found in Middle Horizon Wari contexts at Cerro Baúl and Cerro Mejia (Nash 2002). Although some ceramic wares not typically found in Huaracane contexts were found associated with Terminal Huaracane phase structures not one clearly identifiable sherd conforming Wari or Tiwanaku ceramic styles common to the region was found in these contexts. As a result, I am confident that even though these contexts dated to the early Middle Horizon, they were occupied by those with Huaracane cultural affiliations. Finally, exotic materials were relatively more common in Terminal Huaracane phase contexts in comparison to the earlier time period; both marine shell, including two small fragments of spondylus, and obsidian were found in association with the majority of Terminal Huaracane structures.

Many, but not all of the Terminal Huaracane structures were associated with level open patio-like areas. The living floors of Terminal Huaracane structures were relatively dirty, especially in comparison to Late Huaracane contexts, as they had high densities of artifacts, bone fragments, and charcoal upon them. The large size of these dwellings and their attached open areas, and the high density of artifacts found in the excavated contexts suggest that many activities may have taken place within and around these structures.

The structure excavated in Unit 3 had a very well defined stone wall foundation that was clearly 


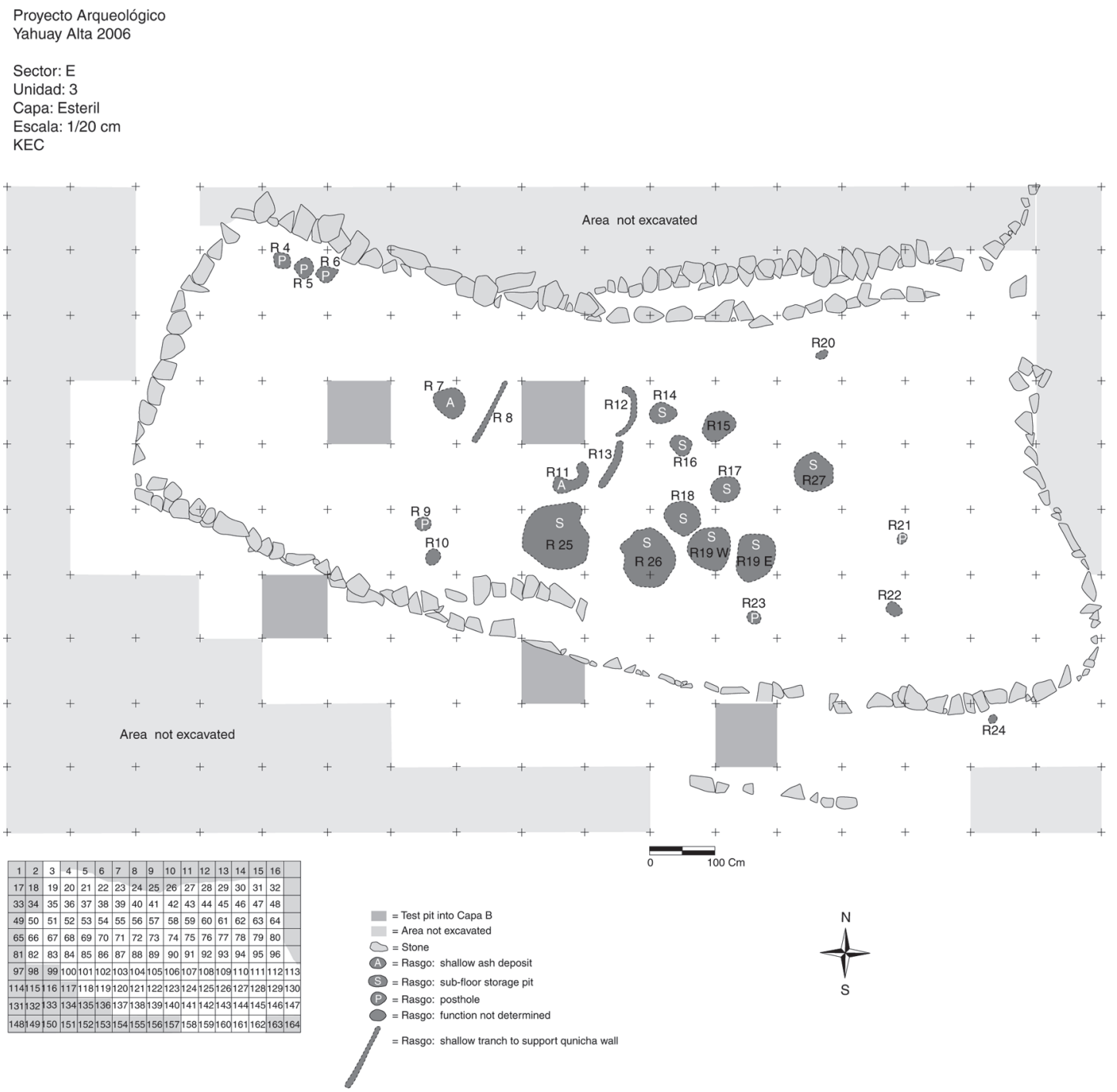

Figure 7. Plan view drawing of Unit 3 excavated to the surface of occupation.

Vista del plano de la Unidad 3 excavado en la superficie de ocupación.

visible upon the surface of the site (Figure 7). This is the largest identifiable structure at Yahuay Alta, other than the platform mound. The foundation of this structure is roughly rectangular in shape and encloses an area approximately $14 \mathrm{~m}$ by $7 \mathrm{~m}$. For most of this structure only the wall foundation is preserved, but in places the back or more northern wall is preserved to a height of approximately $1.5 \mathrm{~m}$. The surface of the structure's interior and the slope in front, south, of the structure was covered with stone wall fall suggesting this structure had walls made at least partially from stone. There is a small, approximately $2 \mathrm{~m}$ long, badly preserved terrace located just in front of this structure. Finally, there was an approximately $1 \mathrm{~m}$ high and $70 \mathrm{~cm}$ wide bench along the eastern half of the back, or northern, wall of this structure. The structure in Unit 3 was clearly very large, especially by Huaracane standards; however the entire area enclosed by the stone wall foundation does not appear to have been a large single room roofed structure. The evidence suggests the interior may have been subdivided into rooms or areas by organic materials; some of these areas may have been roofed and others were probably not. A concentration of three well-preserved postholes in the northwestern corner seems to suggest this area 
towards the back of the structure was roofed. There also seems to have been a small room made from woven reed, or quincha, walls near the center of the structure. In this area, three narrow trenches were dug into the floor enclosing a small area. These trenches could easily have supported lightweight quincha walls. Just to the east and south of this small enclosed room, there was a concentration of nine sub-floor storage pits of varying sizes that were excavated in to the bedrock of the site.

The structure in Unit 5 (Figure 8) was constructed on a long narrow terrace halfway up the terraced hill that comprises most of Sector C. This terrace was approximately $8 \mathrm{~m}$ by $2.5 \mathrm{~m}$ and had a partially preserved curving stone retaining wall. It is difficult to determine the exact nature of the structure built upon this terrace because no postholes or other structural features were preserved. However, the surface of the terrace did have a badly preserved living surface upon which some domestic refuse was recovered suggesting that a dwelling was constructed in this location. This terrace also contained a well-made, stone-walled, square basin similar in construction to the basin found in Unit 1 and two large sub-floor storage pits excavated into the bedrock of the site. There is no evidence that the terrace in Unit 5 was subdivided into areas or rooms, it appears that one simple structure was constructed in this location.

Unit 6 was easily the most complicated context excavated at Yahuay Alta because it included multiple structures, one of which included a human burial and evidence for multiple occupations (Figure 9). The northwestern section of this context included a structure with a roughly rectangular stone wall foundation that was approximately $5 \mathrm{~m}$ by $4.5 \mathrm{~m}$ at its maximum. This structure was constructed above a preserved earlier living surface suggesting this section of the site was remodeled during the Terminal Huaracane phase. Unfortunately, no appropriate samples for radiocarbon dating were found in association with this earlier occupation. To the south and east of the rectangular structure was an open patio area where some patches of a preserved compacted soil living surface were found. Connected to the rectangular structure by a continuous stone wall that also served as a front retaining wall to the terrace immediately behind and above this unit was a structure with a roughly oval stone wall foundation with a maximum diameter of approximately $3 \mathrm{~m}$. This was a semi-subterranean structure with a hardened clay floor upon which the remains of an adult human deposited under two large broken Huaracane Fibre Vegetal ollas were discovered. There was an open patio area in front of the oval structure that was between approximately $5 \mathrm{~cm}$ and $10 \mathrm{~cm}$ above the level of the patio area mentioned above. A badly preserved curving line of stones helped to separate these two patio areas.

Only one posthole was preserved in the rectangular structure in Unit 6. Nevertheless, this suggests that at lest part of this structure was roofed using organic materials. Since there was only one posthole in this structure it is difficult to tell if it was internally subdivided or if the entire structure was roofed. There are no postholes associated with the oval, semi-subterranean structure so it is difficult to determine if it was roofed. However, its oval stone foundation could have easily supported a lightweight quincha wall. There is an irregularly spaced group of five postholes in the open patio area to the east of the oval structure in the southeast corner of Unit 6 . This suggests that there may have been a simple structure constructed of organic materials located in this patio.

Unit 8 consisted of two areas or sections (Figure 10). There was a small rectangular structure defined by a $5.5 \mathrm{~m}$ by $2.5 \mathrm{~m}$ low stone wall foundation in the southern section of the unit and a large, $6 \mathrm{~m}$ by $4.5 \mathrm{~m}$, open patio area with a front stone retaining wall in the northern section of the unit. The open patio area was artificially leveled using a rocky construction fill that was over $50 \mathrm{~cm}$ deep in some location. The smaller rectangular structure is elevated approximately $10 \mathrm{~cm}$ to $20 \mathrm{~cm}$ above the surface of the patio and is separated from this open area by a shared stone retaining wall. Nine well-preserved postholes, and three possible postholes, were found in Unit 8 demonstrating that the walls of the structure in this context were most likely constructed from organic materials. Four of these postholes were located in the patio area suggesting that at least the back portion of this open area closest to the small rectangular structure may have been roofed. It appears that only the more eastern half of the small rectangular structure was roofed, as there are no postholes in the more western half of this structure. Thirteen sub-floor storage pits excavated into the bedrock were found in the small rectangular structure and in the patio along the wall that separates it from the rectangular structure. In 


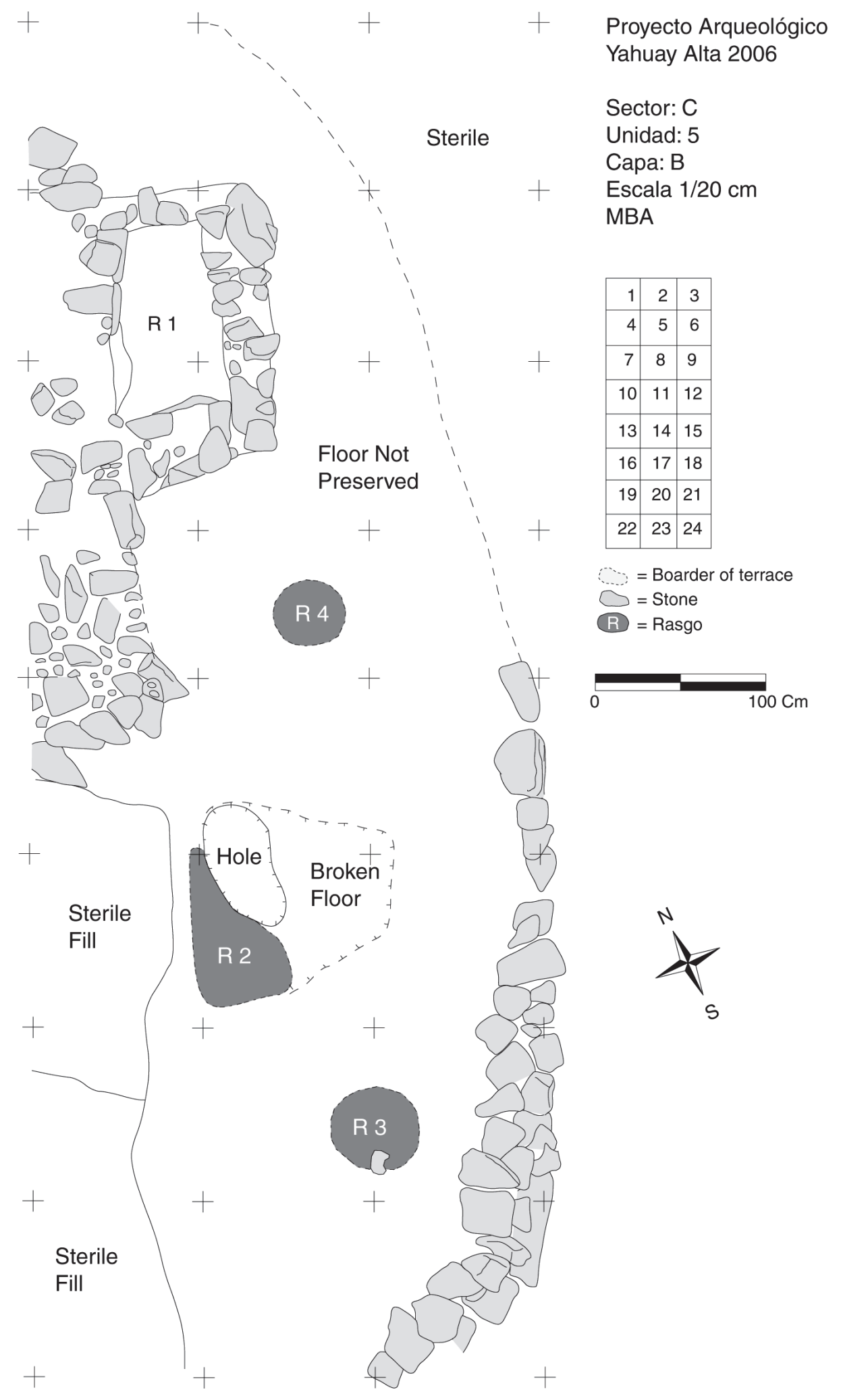

Figure 8. Plan view drawing of Unit 5 excavated to the surface of occupation (drawn by Monika Barrionuevo Alba). Vista del plano de la Unidad 5 excavado en la superficie de ocupación (dibujado por Monika Barrionuevo Alba). 
Proyecto Arqueológico Yahuay Alta 2006

Sector: C

Unidad: 6

Areas: A,B,C,D,E

Capa: $B$ (living surface)

Escala: $1 / 20 \mathrm{~cm}$

MBA

$$
\begin{aligned}
& =\text { Area not excavated } \\
& =\text { Broken floor } \\
& =\text { Hard clay floor } \\
& =\text { Stone } \\
\mathbb{B} & =\text { Rasgo } \\
& =\text { Border of area } \\
& =\text { Hole } \\
\text { A } & =\text { Ash deposit } \\
\text { P } & =\text { Posthole }
\end{aligned}
$$

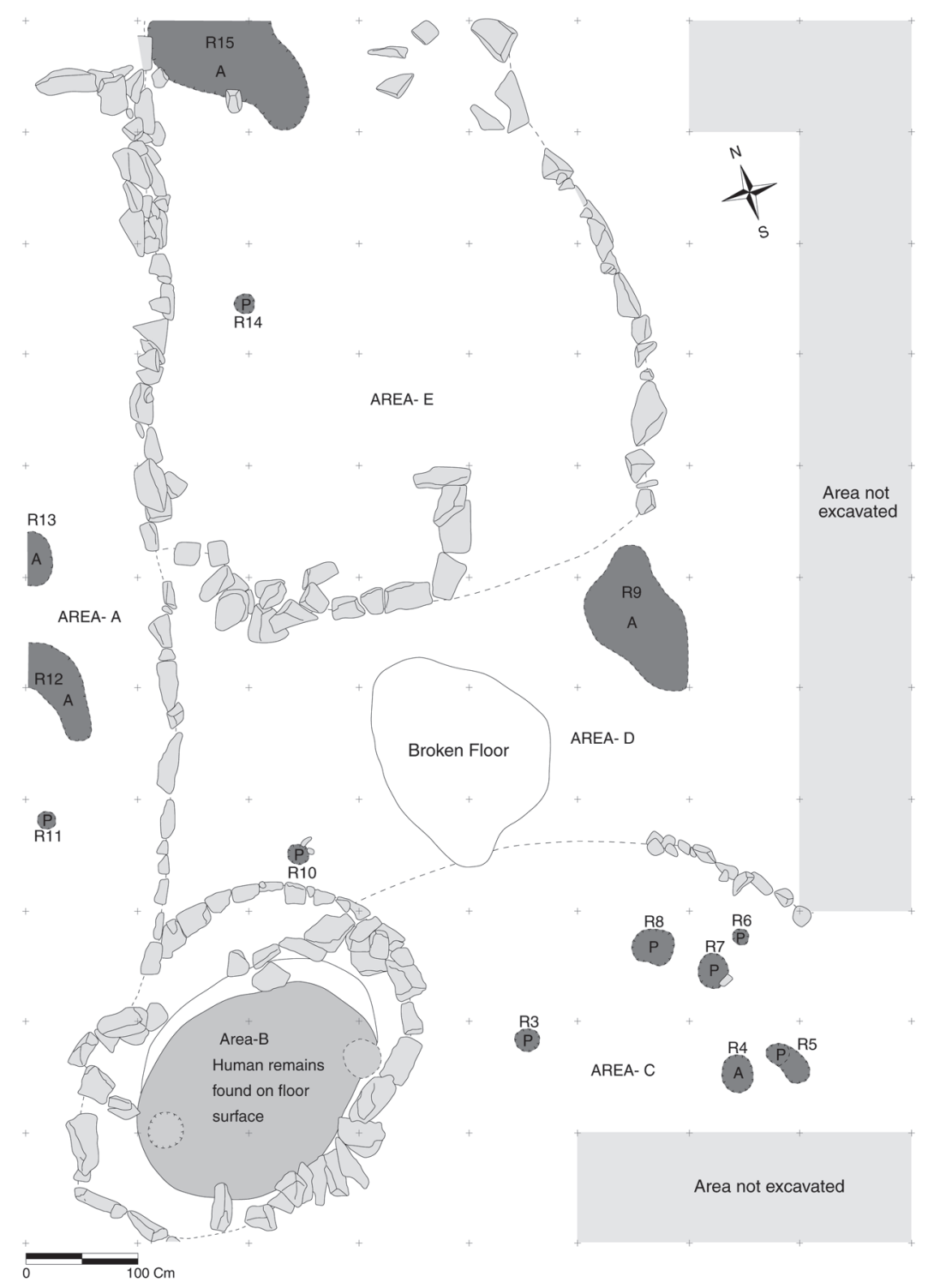

Figure 9. Plan view drawing of Unit 6 excavated to the surface of occupation (drawn by Monika Barrionuevo Alba).

Vista del plano de la Unidad 6 excavado en la superficie de ocupación (dibujado por Monika Barrionuevo Alba).

addition, a well-made partially stone-walled basin with an extremely hard prepared clay floor was situated in the southwestern corner of the patio area.

Unit 7 was the only non-domestic context excavated at Yahuay Alta. The structure in this context was situated directly adjacent and to the west of the platform mound and was thus part of the site's public ceremonial complex (Figure 11). The roughly rectangular structure in Unit 7 was at its maximum approximately $7 \mathrm{~m}$ by $3 \mathrm{~m}$. This structure had well-preserved stone wall foundations, although part of the front wall was badly destroyed in a section that possibly served as an entrance. This structure was surrounded and filled by a very large amount of stone wall fall suggesting that it had relatively high stone walls. In places where they are well preserved, such as the southeastern corner, it is clear that these stone walls were well built with smooth faced stones. Despite having high stone walls, it appears that at least the southern 


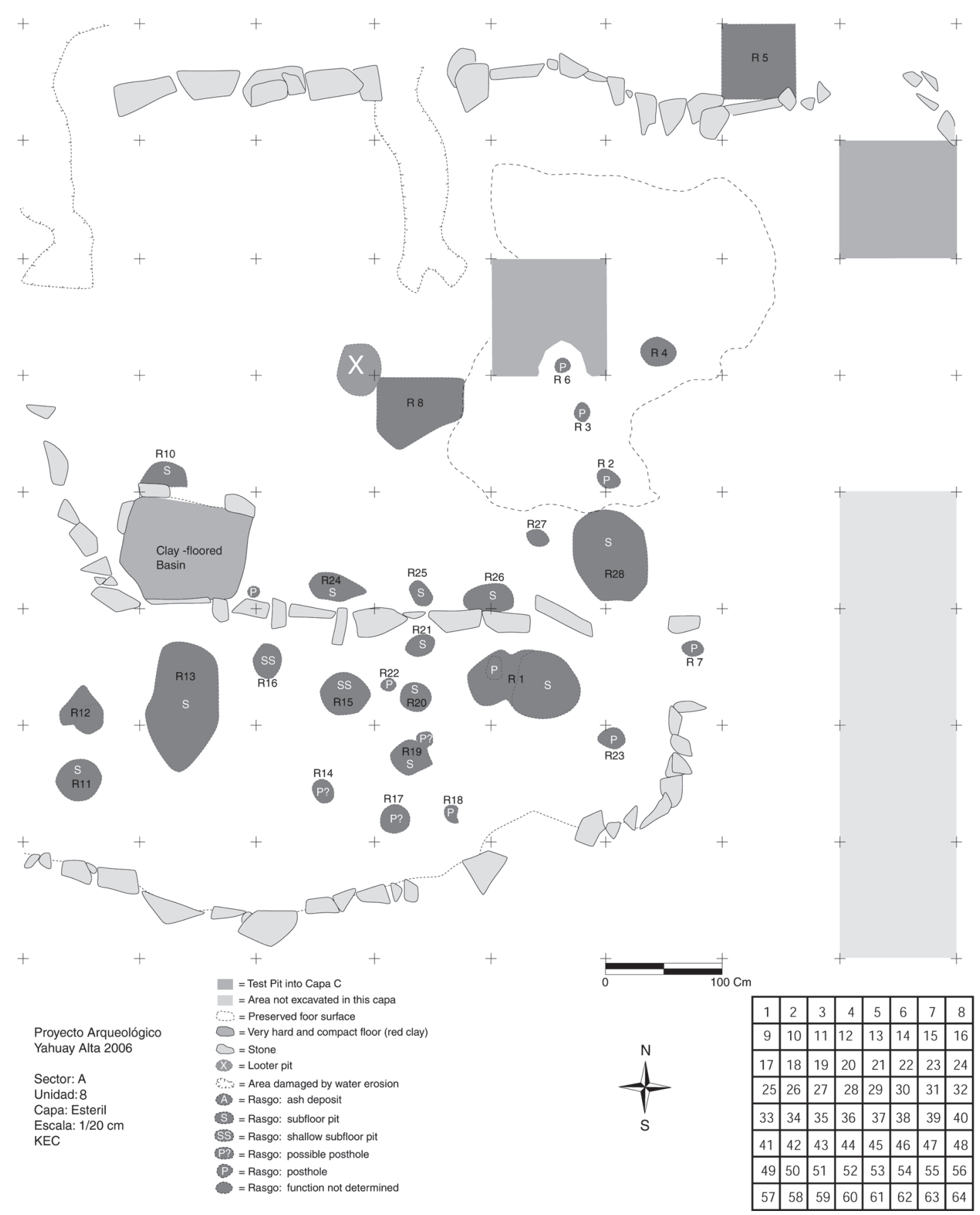

Figure 10. Plan view drawing of Unit 8 excavated to the surface of occupation. Vista del plano de la Unidad 8 excavado en la superficie de ocupación.

and narrower half of this structure was roofed using organic materials as three well-preserved postholes were found in this half of the structure. It is not clear weather or not the northern half of the structure was roofed as only one very small posthole was found in this context. Five sub-floor storage pits excavated into the site's bedrock were found in this structure. Three of these sub-floor pits were filled almost completely with Schinus molle seeds. In total, more than $4 \mathrm{~kg}$ of Schinus molle 


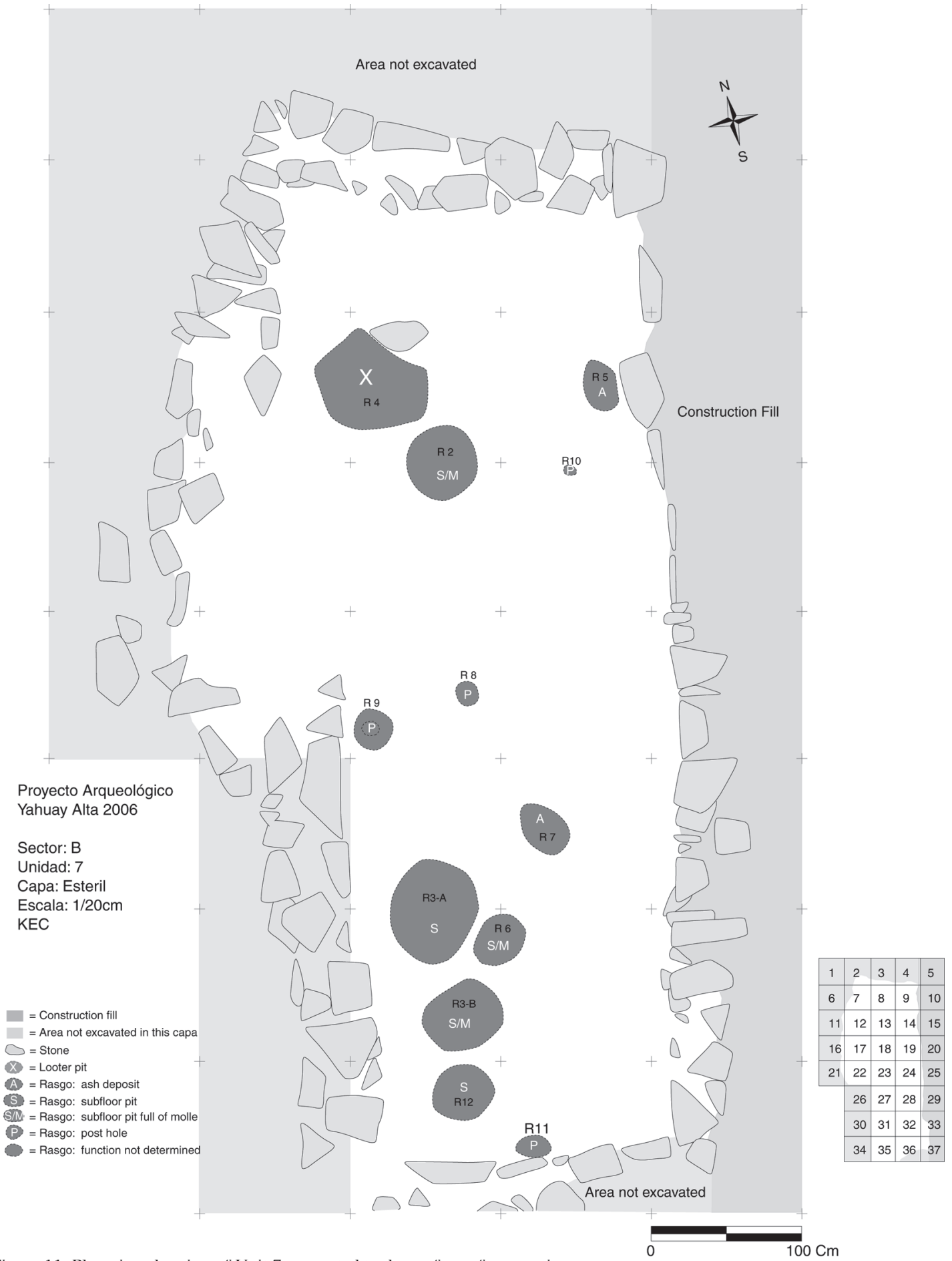

Figure 11. Plan view drawing of Unit 7 excavated to the surface of occupation. Vista del plano de la Unidad 7 excavado en la superficie.

seed were recovered from these three pits. It is of note that pits similar to the three Schinus molle pits discovered in Unit 7 have been found associated with the monumental brewery at the nearby imperial Wari center of Cerro Baúl (Costion 2012; Goldstein et al. 2009; Moseley et al. 2005). 


\section{Conclusions}

The purpose of this article was to briefly introduce the contexts at Yahuay Alta from which recent radiocarbon dates were obtained. Unfortunately there is not space in this format to adequately discuss the results of the analysis of all the data recovered from these contexts in detail. The evidence discussed here suggests there were some dramatic differences between the Late Huaracane contexts and the Terminal Huaracane contexts at Yahuay Alta. During the Late Huaracane the residents of Yahuay Alta were residing in circular structures similar to those found at typical Huaracane sites throughout the middle Moquegua valley. This evidence in addition to the Huaracane style ceramics found in these contexts suggests that during this time period Yahuay Alta was a typical Huaracane community. However, during the Terminal Huaracane phase the residents of Yahuay Alta were residing in rectangular structures that were distinctly atypical of those found at any documented Huaracane sites. Despite this major difference, a minimum of $82 \%$ of the ceramics from all excavated Terminal Huaracane contexts, with the single exception of Unit 3, were Huaracane in style. In Unit 3 only $44 \%$ of the ceramics were Huaracane in style, the most predominate ceramics in this context were constructed from the atypical ware containing a large amount of biotite mica temper mentioned above. Notwithstanding this exception, I believe that this evidence suggests that the Terminal Huaracane phase residents at Yahuay Alta were culturally Huaracane.

The primary reason for the observed differences between Late Huaracane phase and Terminal Huaracane phase context is almost certainly related to the presence of Wari and Tiwanaku populations in the Moquegua valley during the Terminal Huaracane phase. During this time period, the residents at Yahuay Alta appear to have adopted some more typically Middle Horizon practices, such as the use of rectilinear residential structures. There is even evidence at Yahuay Alta for the adoption or emulation of the specifically Wari practice of utilizing Schinus molle seeds to make chicha (Costion 2012; Goldstein et al. 2009; Nash 2011). Despite the major changes that took place at Yahuay Alta during the Terminal Huaracane phase, the residents of this site continued to maintain a distinctly Huaracane identity, in fact as mentioned above no
Wari or Tiwanaku style artifacts were found during the investigations at Yahuay Alta. It is important to note that during an informal survey in 1994 Bruce D. Owen found several clearly identifiable Wari sherds on the easternmost ridge of Yahuay Alta approximately $300 \mathrm{~m}$ from the section of the site investigated in 2006 (Owen 2012). Nevertheless, I do not believe that the presence of a few Wari sherds on the site in any way changes my interpretation that the Terminal Huaracane community at Yahuay Alta maintained a somewhat traditional Huaracane identity. Possibly the general lack of Wari or Tiwanaku material culture or even the emulation of this material culture at Yahuay Alta suggests that this community desired to be left alone and to stay out of the regional political battles that were likely taking place between the Wari and Tiwanaku colonists. Perhaps by remaining at least outwardly 'unaffiliated' with either the Wari or the Tiwanaku, this Huaracane community was able to stay off the radar of the colonial powers and continue a relatively traditional way of life.

Acknowledgments: Funding to support the research conducted at Yahuay Alta in 2006 was provided by National Science Foundation (Dissertation Improvement Grant \#0628963). In addition, a Graduate Student Field Research Grant from the University of Pittsburgh's Center for Latin American Studies and an International Studies Fund Research Grant from University of Pittsburgh's University Center for International Studies provided support for preliminary investigations at Yahuay Alta in 2004. I am very grateful for the support provided to me by the Museo Contisuyo, its director Antonio Oquiche, and all of the Museo's staff throughout my entire stay in Moquegua. The radiocarbon dates presented in this article were processed with the help of Mark Abott and two of his students (Nathan Stansell and Broxton Bird). My research at Yahuay Alta and subsequent data analysis would not have been possible without the help and intellectual support of the following individuals: Monika Barrionuevo Alba, Marc P. Bermann, Eloy Calizaya, Maria Acero Condori, Robert D. Drennan, Robert A. Feldman, Hugo Flores, David J. Goldstein, Paul S. Goldstein, Luis Gonzales, Michael E. Moseley, Lizette Muñoz Rojas, Donna J. Nash, Gumercindo Quispe, James B. Richardson III, Julie Sapienza, Kenneth Y. Sims, and Patrick Ryan Williams. Finally I would like to thank the two anonymous reviewers who provided 
insightful comments on the final manuscript. As always, although this research would not have been possible without the help of all the aforementioned people and institutions, I take sole responsibility for any errors, misinterpretations, or omissions in this article.

\section{References Cited}

Bandy, M.S. 1995. The early ceramic periods of Moquegua: a reappraisal. Presented in 60th Annual Meetings of the Society for American Archaeology, Minneapolis, MN.

Costion, K. 2012. Huaracane production and consumption of chicha de molle at Yahuay Alta: an example of indigenous agency in a colonial landscape. Presented in 77th Annual meeting of the Society for American Archaeology, Memphis, TN.

Costion, K. and U.M. Green 2009. Rethinking the local experience: responses to Middle Horizon expansion in the Andes. Presented in 74th Annual Meeting of the Society for American Archaeology, Atlanta, GA.

de Silva, S., J. Alzueta and G. Salas 2000. The socioeconomic consequences of the A.D. 1600 eruption of Huaynaputina, southern Peru. Geological Society of America Special Paper 345:15-24.

Feldman, R.A. 1989. The early ceramic periods of Moquegua. In Ecology, Settlement and History in the Osmore Drainage, Peru, edited by D.S. Rice, C. Stanish and P.R. Scarr, pp. 207217. BAR International Series 545(i). British Archaeological Reports, Oxford.

Flannery, K.V. 1983. The Tierras Largas phase and the analytical units of the early Oaxacan village. In The Cloud People: Divergent Evolution of the Zapotec and Mixtec Civilizations, edited by K.V. Flannery and J. Marcus, pp. 43-46. Academic Press, New York.

Goldstein, D. J., R.C. Goldstein and P.R. Williams 2009. You are what you drink: reconstructing Middle Horizon (500-1000 C.E.) social dynamics through paleoethnobotanical interpretations of fermented beverage production and consumption at Cerro Baúl, Moquegua, Perú. In Drink, Power, and Society in the Andes, edited by J. Jennings and B. Bowse, pp. 133-166. University of Florida Press, Gainesville.

Goldstein, P.S. 1989. Omo, A Tiwanaku Provincial Center in Moquegua, Peru. Unpublished Ph.D. Dissertation, The University of Chicago, Chicago.

- _ _ 1993a. House, community, and state in the earliest Tiwanaku colony: domestic patterns and atate integration at Omo M12, Moquegua. In Domestic Architecture, Ethnicity, and Complementarity in the South-Central Andes, edited by M.S. Aldenderfer, pp. 25-41. University of Iowa Press, Iowa City.

_ _ _ 1993b. Tiwanaku temples and state expansion: a Tiwanaku sunken-court temple in Moquegua, Peru. Latin American Antiquity 4:22-47.

- _ 2 2000a. Communities without borders: the vertical archipelago model and diaspora communities in the southern Andes. In The Archaeology of Communities: A New World Perspective, edited by M. A. Canuto and J. Yaeger. vol. 182209. Routledge, London.

_ _ _ 2000b. Exotic goods and everyday chiefs: long-distance exchange and indigenous sociopolitical development in the south central Andes. Latin American Antiquity 11:335-361.
_. _ 2005. Andean Diaspora: The Tiwanaku Colonies and the Origins of South American Empire. University Press of Florida, Gainesville.

Green, U.M. and P.S. Goldstein 2010. The nature of Wari presence in the mid-Moquegua valley: domestic contact at Cerro Trapiche. In Beyond Wari Walls: Regional Perspectives on Middle Horizon Peru, edited by J. Jennings, pp. 19-36. University of New Mexico Press, Albuquerque.

Moseley, M.E., R.A. Feldman, P.S. Goldstein and L. Watanbe 1991. Colonies and conquest: Tiahuanaco and Huari in Moquegua. In Huari Administrative Structure: Prehistoric Monumental Architecture and State Government, edited by W.H. Isbell and G.F. McEwan, pp. 121-140. Dumbarton Oaks, Washington, D.C.

Moseley, M.E., D.J. Nash, P.R. Williams, S. deFrance, A. Miranda and M. Ruales 2005. Burning down the brewery: establishing and excavating an ancient imperial colony at Cerro Baúl, Peru. Proceedings of the National Academic of Science 102:17264-17271.

Nash, D.J. 2002. The Archaeology of Space: Places of Power in the Wari Empire. Unpublished Ph.D. dissertation, University of Florida, Gainesville.

_ _ _ 2011. Fiestas y la economía política wari en Moquegua, Perú. Chungara Revista de Antropología Chilena 43:221-242.

Owen, B.D. 2005. Distant colonies and explosive collapse: the two stages of the Tiwanaku diaspora in the Osmore drainage. Latin American Antiquity 16:45-80.

_ _ _ 2012. Ceramic and textile evidence of Wari interactions with Osmore Drainage populations from the sierra to the coast. Presented in 77th Annual meeting of the Society for American Archaeology, Memphis, TN.

Reimer, P., M. Baillei, E. Bard, A. Bayliss, J. Beck, C. Bertrand, P. Blackwell, C. Buck, G. Burr, K. Cutler, P. Damon, R. Edwards, R. Faribanks, M. Friedrish, T. Guilderson, K. Hughen, B. Kromer, F. McCormac, S. Manning, C. Bronk Ramsey, R. Reimer, S. Remmele, J. Southon, M. Stuiver, S. Talamo, F. Taylor, J. van der Plicht and C. Weyhenmeyer 2004. IntCal04 terrestrial radiocarbon age calibration, 26-0 ka BP. Radiocarbon 46:1029-1058.

Wernke, S.A. 2011. Asentamiento, agricultura y pastoralismo durante el periodo formativo en el valle del Colca, Perú. Chungara Revista de Antropología Chilena 43:203-220.

Williams, P.R. 2001. Cerro Baúl: a Wari center on the Tiwanaku frontier. Latin American Antiquity 12:67-83.

_ _ _ - 2002. Rethinking disaster-induced collapse in the demise of the Andean highland states: Wari and Tiwanaku. World Archaeology 33:361-374.

Williams, P.R. and D.J. Nash 2002. Huari and Tiwanaku at Cerro Baúl. In Andean Archaeology I, edited by W.H. Isbell and H. Silverman, pp. 243-266. Kluwer Academic, New York. 


\section{Notes}

1 This site was originally termed simply as Yahuay (or Yaway) by Feldman (1989) and given the site number M35. I have elected to term the sections of the site located up on the slopes of Cerro Estuquiña as Yahuay Alta in order to distinguish this settlement from the residential and cemetery sites located upon the Pampa Yahuay below.
2 The elevation contour lines and the locations of many of the terraces on this map of Yahuay Alta were obtained with permission from an unpublished map of the site produced in 1983 by Robert A. Feldman. 
